\title{
Rural Library Sustainability Development: A Case Study in Langkawi
}

Siti Khadijah Rafie, Roziya Abu, Ranita Hisham

To Link this Article: http://dx.doi.org/10.6007/IJARBSS/v10-i12/8107

DOI:10.6007/IJARBSS/v10-i12/8107

Received: 10 October 2020, Revised: 07 November 2020, Accepted: 29 November 2020

Published Online: 15 December 2020

In-Text Citation: (Rafie et al., 2020)

To Cite this Article: Rafie, S. K., Abu, R., \& Hisham, R. (2020). Rural Library Sustainability Development: A Case Study in Langkawi. International Journal of Academic Research in Business and Social Sciences, 10(12), 296-308.

\section{Copyright: (c) 2020 The Author(s)}

Published by Human Resource Management Academic Research Society (www.hrmars.com)

This article is published under the Creative Commons Attribution (CC BY 4.0) license. Anyone may reproduce, distribute, translate and create derivative works of this article (for both commercial and non-commercial purposes), subject to full attribution to the original publication and authors. The full terms of this license may be seen at: http://creativecommons.org/licences/by/4.0/legalcode

\section{Vol. 10, No. 12, 2020, Pg. 296 - 308}

Full Terms \& Conditions of access and use can be found at http://hrmars.com/index.php/pages/detail/publication-ethics 


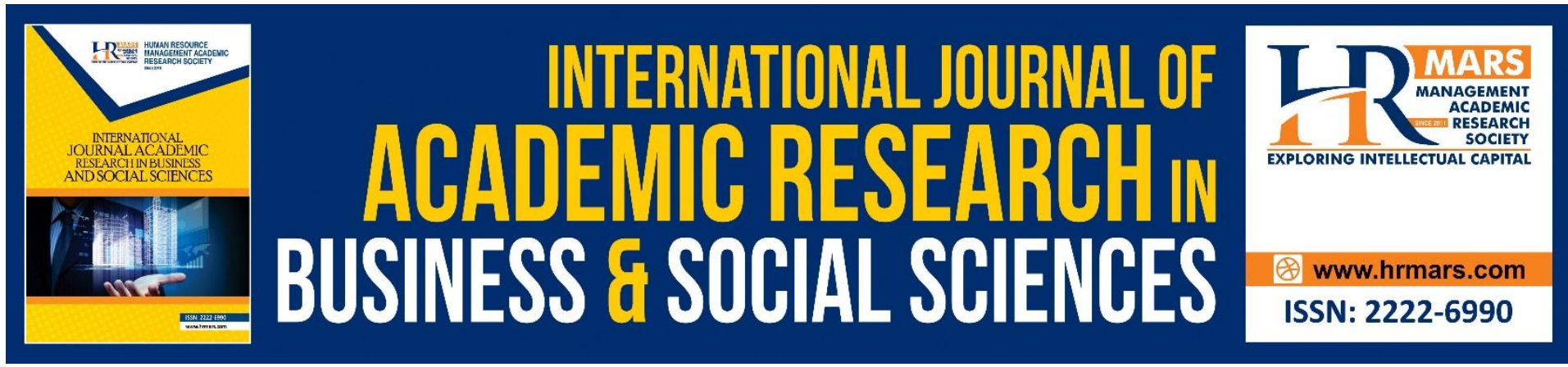

\title{
Rural Library Sustainability Development: A Case Study in Langkawi
}

\author{
Siti Khadijah Rafie \\ Universiti Teknologi MARA Cawangan Kedah \\ Assoc. Prof. Dr. Roziya Abu \\ Universiti Teknologi MARA Cawangan Selangor \\ Dr. Ranita Hisham \\ Universiti Malaya
}

\begin{abstract}
The sustainability concept has been widely discussed in various fields nowadays. In Malaysia, sustainability is highlighted in the 11th Malaysia Plan with the focus of improving human wellbeing, green environment, infrastructure that supports the Malaysian economic development, and the empowerment of public servants with high productivity. Sooner or later, all organizations in Malaysia will be implementing sustainability elements in their procedures. Now, it is time for libraries to be in line with this trend to ensure their existence. This study, therefore, seeks to identify the sustainability elements needed by rural libraries to sustain in the community and continuously provide information to the community. A rural library in Langkawi is the focus of this study. The staff, the user, and the non-user of the rural library were interviewed on the environmental, economic, and social sustainability elements.
\end{abstract}

Keywords: Sustainability, Environmental Sustainability, Economic Sustainability, Social Sustainability.

\section{Introduction}

The National Library of Malaysia was established in Kuala Lumpur in 1972 to make library resources available to the Malaysian public and to act as a store for collections of national interest. It holds an organized collection of books, other printed materials, and special documents such as films and audio materials. The main functions of the National Library of Malaysia are divided into three, namely 1) management, 2) library development, and 3) information services. Meanwhile, the establishment of rural libraries in Malaysia as a social and cultural hub for the community has forced NLM to rebrand these rural libraries into a center of community information and knowledge, which involves rural library governance, administration, infrastructure, and human resource.

In the beginning, four new rural libraries in different states in Malaysia were chosen as a pilot project. These four rural libraries are well-equipped with reading materials such as books, 
magazines, newspapers, and facilities such as computers and internet connection. The libraries are also equipped with nice landscaping and recreational facilities to attract the surrounding community to obtain knowledge and utilize the library facilities for study, business purposes, or leisure. By December 2016, NLM had managed 510 rural libraries, whereas 611 rural libraries are managed by the respective state government. Although the Malaysian rural libraries are ministered by two different bodies (NLM and State Government), NLM maintains its roles by supporting all rural libraries financially and infrastructurally. The government of Malaysia through NLM has also shown their commitment to enhancing the quality of life in the rural areas by allocating an operating budget of Ringgit Malaysia (RM) 38.377 million (USD 8.6 million) for the 510 rural libraries to strengthen the libraries' infrastructure and facilities. To date, the total cumulative library collection in rural libraries is $11,076,412$ copies.

The Langkawi Rural Library is a community rural library established by NLM in the year 2006. This rural library was constructed with a special budget allocated by the Malaysian Government through the National Library of Malaysia. The main objective of the Langkawi rural library is to encourage reading habits and fulfill the knowledge gap among the rural and urban communities of Langkawi. This rural library is located in the Kuah district, nearby Kampung Syed Nahar in Langkawi Island, Kedah. Demographically, the Langkawi rural library serves about 500 village people and this rural library can accommodate 40 users at a time. The collections available at the library include books, magazines, and newspapers. The wireless internet has also been provided to users to search for online information. Since a large number of its community are Muslims, the Langkawi rural library is located within the local community mosque compound, which is considered very strategic.

Based on numerous studies in the context of sustainability, a rural library upholds its survival to ensure its continuous relevance in its community based on the three elements of sustainability, namely 1) environmental sustainability, 2) economic sustainability, and 3) social sustainability. This article discusses and offers insight into the sustainability development of the Langkawi rural library.

\section{Problem Statement}

Sustainability in any rural libraries is very crucial since rural libraries act as a mechanism that benefits its community. In general, the sustainability concept defines sustainability as fulfilling the needs of the current generation without affecting the future (Kuhlman \& Farrington, 2010). This term arises from the thinking of how the development of the world nations could be reconciled with limited resources and environmental degradation. There can be many sustainability elements; however, the three main pillars of sustainability are environmental, economic, and social (Emas, 2015; Giovannoni \& Fabietti, 2014) This also refers to the capacity to indeterminately continue an activity that can be related to the environmental, economic, and social activity elements that have a variant meaning depending on their disciplines (Markulev \& Long, 2013). Sustainability is widely considered an important part of contemporary life and it is even highlighted in the 11th Malaysia Plan. Hence, this leads to the attention to the sustainability concept in libraries, generally, and rural libraries, specifically.

There is a global phenomenon whereby rural libraries are underutilized and closed (Bakeri, Bakar, \& Putri, 2013; Fairbairn, 2012; Jenkins, Quiroga, Quiballo, Peterson, \& Sorrell, 2018). 
Some of the libraries have even transformed into Information Technology (IT) centres (Hoq, 2015). In Malaysia, a large number of rural libraries were reportedly underutilized (Omar et al., 2014; Darwish \& Abdeldayem, 2019). Even so, NLM and the local state public libraries keep doubling their effort to offer more activities and programs to the local rural communities. Nonetheless, sustainability is the key element of rural libraries' survival by which their inability to sustain all activities and services provided to the local community will result in closedown and service termination as a global issue. To prevent such a situation to happen in Malaysia, a sustainability measurement framework should be developed to ensure that the rural libraries will sustain in the community. This study aims to provide a guideline for rural libraries to sustain within the community, based on the three sustainability elements (environment, economic and social). In addition, it would help rural libraries to survive and fully utilised by the local community.

Presently, there are 1,469 rural libraries in Malaysia, 509 of which are handled by the National Library of Malaysia while the rest is handled by the state libraries (Rosham, 2017). Generally, there is insufficient literature on library sustainability and specifically on rural libraries. Karioja in 2013 wrote a thesis on library sustainability that focuses on 'a green library' environment, and he suggested further research on the sustainability concept with a different focus involving economic and social sustainability. Moreover, the International Federation Library Association (IFLA) is already aware of library sustainability; however, the focus is only on the environmental factors and not the social and economic factors. While there is insufficient literature on rural library sustainability, to the best of the researchers' knowledge, no studies have focused on rural library sustainability from the following three (3) aspects: environmental, social, and economic. As such, a previous study has shown that there are many spaces for improvement of sustainability in libraries (Karioja, 2013).

\section{Literature Reviews}

This section focuses on the three pillars of rural library sustainability in this study, namely rural library environmental sustainability, rural library economic sustainability, and rural library social sustainability.

\section{Rural Library Environmental Sustainability}

Environmental sustainability, which is also known as ecological sustainability, is a provision of clean terminological wise such as clean land, clean water, and clean energy to establish land productivity as well as responsible socioeconomic factors (Morelli, 2011). It also refers to the condition of flexibility, balance, and interconnectedness that enable people to fulfill their needs without affecting the supporting ecosystems to regenerate the services necessary to meet the needs. In the context of this study, environmental sustainability in libraries denotes a practice in the aspect of the physical building structure of the libraries, such as using biodegradable materials and adapting such elements in the libraries' procedures and services (Karioja, 2013). In Canada, the rural library building uses a standard development structural system called Leadership in Energy and Environmental Design (LEED), which aims to ensure that the building fulfills the environmental sustainability requirements. Other libraries in Europe have also implemented the environmental sustainability element in their physical building development design and integrated environmental sustainability initiatives in their programs and services (Townsend, 2014). 
Meanwhile, the International Federation Library Association (IFLA) has its Special Interest Group (SIG) focus on the environmental sustainability of libraries. Green libraries are the aim of IFLA in ensuring that the library community is environmentally aware, thereby increasing environmental awareness to all levels including educators and professionals. Green library buildings are said to be following LEED guidelines through sustainable routines such as recycling and decreasing the consumption of natural resources. Green librarianship, on the other hand, consists of green information services such as promoting Current Awareness Services (CAS) with reliable and current environmental information. As such, the role of green librarians includes creating community-related awareness regarding environmental issues (IFLA, 2020).

\section{Rural Library Economic Sustainability}

An economically sustainable system refers to the ability of an organization to continuously produce goods and services to maintain manageable levels of government income and external debts (Harris, 2003). Economic sustainability requires that different kinds of sources that make economic sense can be developed. One of the sturdiest indicators of a sustainable community is a healthy economy (Hancks, 2011), which means that the availability of jobs is sufficient for the community. Indirectly, the community will have a stable life that allows them to sustain. This also means that the community is ensured a continuous income for the current and future generations (Spangenberg, 2005). In this study, rural library economic sustainability refers to the fact that libraries must have control over their financial resources (Michnik, 2015).

Most rural libraries have been facing financial problems that have brought difficulties for them to offer various services to the community (Dent, 2007). Consequently, due to financial problems, rural libraries are also unable to provide Information Communication and Technology (ICT) to their users. Hence, to overcome this problem, a few libraries in Indonesia had taken several initiatives to generate their own income (Kamarudin \& Untari, 2018; Raglina Siti Maskurotunitsa, 2016; Rohman \& Sukaesih, 2018). For instance, they conducted economic activities such as animal husbandry, farming, and handicraft to gain profit.

\section{Rural Library Social Sustainability}

According to Harris (2003) and Yu (2017), a socially sustainable system must achieve the adequate provision of social services including health and education, political accountability, gender equity, social equality, and fair treatment to improve social sustainability. Besides, Yu (2017) also emphasized health and safety as another important element of social sustainability, which has not been highlighted in other studies.

Additionally, social sustainability can be defined as satisfying basic human needs (Jeekel, 2017). Jeekel (2017) also highlighted four (4) orientations of social sustainability: 1) The development of social sustainability that provides better distribution of power, better housing, more freedom, better education, and more worldwide equality; 2) The connection of social sustainability by creating lifestyles and environment that will enhance social sustainability; 3 ) The maintenance of social sustainability that is closely related to social acceptance, which also brings the idea of merging the three pillars of economic, social, and environmental sustainability; 4) The liberation of the social domain as the core issue without many relations to other forms of sustainability. In general, social sustainability in this 
orientation is seen as forming situations of social justice, fairness, and equality, as well as facilitating the notion that working and blooming communities can be sustained. There are many factors of social sustainability to consider, such as education and training, social justice, participation and local democracy, health, quality of life, wellbeing, social capital, community, safety, fair distribution of salary, social order, social and community cohesion, social network, social interaction, sense of community and belonging, employment, active community, and cultural traditions. This is also supported by Vanclay (2002), who mentioned the seven categories of social impacts: health and social well-being, livability, economic and material well-being, cultural, family and community, institutional, political, and equity, and gender relations. In the context of this study, the role of the rural libraries is to fulfill the social needs of the community. Hence, they should promote health and well-being in the community, by which library social sustainability should support community engagement activities among community members.

\section{Theoretical Gap}

Literature reviews exposed the theoretical gap in this study. First, there is few studies highlighted on both environment and economic simultaneously (Arya, Srivastava, \& Jaiswal, 2019; Spodick, 2016). There are very few studies have been found related to the sustainability of rural libraries in the aspects of environment, economic and social (Mansour, 2020). However, this study focus on the three elements namely environment, economic and social. There are insufficient literatures on sustainability in libraries generally and rural libraries specifically.

\section{Research Methodology}

The qualitative approach used in this study is concerned with a qualitative phenomenon that involves quality. The qualitative methodology appears to be the best methodology for this study in a quest for understanding rural library sustainability. A semi-structured interview was conducted to obtain information from the respondents as it enables the researchers to gain an in-depth understanding of the situation. The staff, the user, and the non-user of the rural library in Langkawi were interviewed to identify the challenges and sustainability elements of the rural library. The interview session was held at the library and around the library area.

The Langkawi rural library is one of the multiple case studies selected for this study. By definition, a case study is a specific field or qualitative research method involving an investigation of phenomena as they occur without intervention from the researcher (Connaway \& Powell, 2015). Yin defined a case study as an empirical inquiry that investigates a contemporary phenomenon within its real-life context, especially when the boundaries between the phenomenon and the context are not evident as there will be more variables of interest than data points. As one result relies on multiple sources of evidence with the data converging in a triangulating fashion, another result benefits from the prior development of the theoretical propositions to guide the data collection and analysis. The researchers have support from the National Library of Malaysia (NLM) for this study. The NLM officer has also provided information about the rural library and the staff's contact number to the researchers. 


\section{Data Analysis}

All of the interview data were audio-recorded, transcribed, and checked. The ATLAS.ti version 7 qualitative software was used throughout the process of sorting, arranging, and classifying the data. The data were also read several times to get familiarization. Themes were then created using redundant data, while the infrequent nodes were removed.

\section{Findings and Discussion}

The study was done at a rural library in Langkawi. Three (3) respondents were interviewed: the library staff, a library user, and a library non-user. A few questions related to rural library sustainability were asked to the respondents. Before commencing the interview session, the researchers first briefed about the three (3) elements of sustainability to the respondents for them to understand the concept. The interview questions are attached in the Appendix.

The information of the respondents is stated below.

\begin{tabular}{|l|l|l|l|}
\hline \multicolumn{1}{|c|}{ Respondent } & \multicolumn{1}{c|}{ Gender } & \multicolumn{1}{c|}{ Age } & \multicolumn{1}{c|}{ Occupation } \\
\hline Library Staff & Female & 37 years old & Library Staff \\
\hline User & Female & 32 years old & Housewife \\
\hline Non-User & Female & 40 years old & Small entrepreneur \\
\hline
\end{tabular}

Table 1: Respondents' Information

"We have participated in the communal work organized at this village. We have also cleaned the library. In the future, we will organize environmental awareness programs for the users." Library Staff

"The library has organized communal work to clean the library and the library area." Library User

"I agree if the library organizes activities that will increase environmental awareness among the users." Library Non-User

Based on the interview and the analyzed data, all of the respondents (staff, user, and nonuser) agreed the rural library should adopt the three elements of sustainability. They also agreed that the library should arrange communal work and organize activities that will increase environmental awareness among the community members such as a recycling program, environmental campaign, pollution prevention activity, and many more.

"We do not have any program to assist the local economic activities yet, but we are planning to do so. We want to arrange for a cooking class, baking class, and sewing class." Library Staff

"The library did not help in our economic activities, but I hope that the library could do that for us." Library User

"Maybe the library should cooperate with other agencies to help us generate a side income. They can cooperate with Amanah Ikhtiar Malaysia (AIM) or Jabatan Kemajuan Masyarakat (KEMAS)." Library Non-User 
They also agreed that the library should play its role in assisting them with their local economic activities. The staff told the researchers that the library is yet to adopt any economic sustainability elements; however, they have the intention to do so. For example, a cooking class, sewing class, and baking class are their future plans to assist in the community's economic activities. The user and the non-user also suggested that the library cooperates with other agencies such as Amanah Ikhtiar Malaysia (AIM), Small Medium Enterprises (SME), and Jabatan Kemajuan Masyarakat (KEMAS) to help small entrepreneurs in the village.

"I am aware that the rural library is the medium for the rural community members to get engaged with one another. That is why we organized a lot of activities for the local community such as sports events, coloring contest, etc." Library Staff

"The library has organized a lot of programs, but most of the programs are focused on the children; maybe the library could enhance their activities for the adults and senior citizens." Library User

"I agree that the library is a place for us to socialize, so the library must set up a lot of programs and activities to encourage participation from the local community." Library Non-User

The staff, the user, and the non-user acknowledged that the rural library is the medium for them to engage with one another. As such, the library had implemented social sustainability by organizing a lot of programs for the community such as sports events, coloring contest, reading campaign, Independence Day celebration, and many more. The library user also proposed the library to organize more programs for adults since the existing program is commonly for children. The library user suggested that the library organizes a cooking competition and floristry competition, arranges health check-ups, or organizes a religious talk for senior citizens. The non-user, who has not used the library due to time constraints also felt that the library should continuously organize programs and activities that enable the community to socialize.

It has been proven that rural libraries need to sustain and stay relevant in the community. As the staff is aware of the importance of adopting sustainability elements in the library, the same goes for the user and non-user of the library. According to the staff, the only challenge was to adjust the limited budget given by NLM to organize activities. Hence, the staff told the researchers that they might be able to do more if more budget is allocated for the library.

The staff has initiatives to provide environmental, economic, and social programs such as gotong-royong (communal work), skill classes, sports events, and many more. The user and non-user also unanimously agreed that the library should assist in the local economic activities. They reached the point of agreement that the library is a medium for the community members to get engaged with one another. Hence, it is recommended that rural libraries in Malaysia implement these sustainability elements (environmental, economic, and social) in their procedures, activities, and programs to ensure their sustainability in the community. All of the respondents also told the researchers that they hope for the rural library to be sustained because it gives benefits to the community, especially in providing information. In addition, the rural library's staff is a reference to the community. 


\section{Conclusion}

In conclusion, sustainability elements (environmental, economic, and social) in rural libraries in Malaysia are very important for ensuring the sustainability of rural libraries in the community and providing information to the rural community continuously. In addition, this study will fulfill the research gap of sustainability in libraries, especially the rural libraries. The National Library of Malaysia (NLM), rural libraries, and librarians will get significant advantages in providing better services, collections, and programs needed by the rural community they serve, rather than standardizing them due to the different needs of each community. Consequently, these efforts will lead to the full utilization of rural libraries. Rural libraries and librarians are offered significant advantage in developing rural libraries, organized programs, activities, providing services and collections which will fulfill local community needs. An additional key contribution of this study is to create awareness among community to fully utilize collections and services provided by the rural library. Furthermore, the results would serve as a basis for sustainable development framework for rural libraries and will lead towards sustainability of rural libraries that could be applicable to other similar national/international rural library contexts. The industry will be able to utilize this framework as a guideline or reference to ensure rural libraries sustainability in Malaysia.

\section{References}

Arya, P., Srivastava, M. K., \& Jaiswal, M. P. (2019). Modelling environmental and economic sustainability of logistics. Asia-Pacific Journal of Business Administration, 12(1), 73-94. https://doi.org/10.1108/APJBA-11-2018-0204

Bakeri, A., Bakar, A., \& Putri, N. L. J. (2013). Sustainability through website development : The case of public libraries in Malaysia.

Connaway, L. S., \& Powell, R. R. (2015). Basic Research Methods for Librarians. PhD Proposal (Vol. 1). Libraries Unlimited. https://doi.org/10.1017/CBO9781107415324.004

Darwish, S., \& Abdeldayem, M. M. (2019). Risk Management and Business Ethics: Relations and Impacts in the GCC. International Journal of Civil Engineering and Technology, 10(10), 489-504.

Dent, V. F. (2007). Local economic development in Uganda and the connection to rural community libraries and literacy. New Library World, 108(5/6), 203-217. https://doi.org/10.1108/03074800710748777

Emas, R. (2015). The Concept of Sustainable Development: Definition and Defining Principles, Florida International University. Brief for GSDR 2015, 1-3. Retrieved from https://s3.amazonaws.com/academia.edu.documents/43652555/5839GSDR_2015_SD _concept_definiton_rev.pdf?response-content-disposition=inline\%3B filename\%3DThe_Concept_of_Sustainable_Development_D.pdf\&X-AmzAlgorithm=AWS4-HMAC-SHA256\&X-Amz-Credential=AKIAIWOW

Fairbairn, J. (2012). Public libraries - an underused resource for development. Retrieved from

http://www.scidev.net/index.cfm?originalUrl=global/communication/opinion/publiclibraries-an-underused-resource-fordevelopment.html\%5Cnhttp://www.scidev.net/global/communication/opinion/publiclibraries-an-underused-resource-for-development.html

Giovannoni, E., \& Fabietti, G. (2014). Integrated Reporting: Concepts and Cases that Redefine Corporate Accountability. In C. Busco, M. L. Frigo, A. Riccaboni, \& P. Quattrone (Eds.), Integrated Reporting: Concepts and Cases that Redefine Corporate 
Accountability (pp. 21-42). Switzerland. https://doi.org/10.1007/978-3-319-02168-3

Hancks, J. W. (2011). Keepin' it rural: The role of rural public library educational programming and outreach in community economic sustainability efforts.

Harris, J. M. (2003). Sustainability and sustainable development. Environmental Impact Assessment Review, 18(6), 493-520. https://doi.org/10.1016/S0195-9255(98)00019-5

Hoq, K. M. G. (2015). Rural library and information services, their success, failure and sustainability: a literature review. Information Development, 31(3), 294-310. https://doi.org/10.1177/0266666913515693

Jeekel, H. (2017). Social sustainability and smart mobility : Exploring the relationship. Transportation Research Procedia, 25, 4300-4314. https://doi.org/10.1016/j.trpro.2017.05.254

Jenkins, J. L., Quiroga, G., Quiballo, K., Peterson, H. A., \& Sorrell, R. (2018). Rural and Small Public Libraries: Challenges and Opportunities. Advances in Librarianship, 43, 37-59. https://doi.org/10.1108/S0065-283020170000043003

Kamarudin, K. H., \& Untari, R. (2018). Development of creative village and rural entrepreneurship in Malaysia and Indonesia : An exploratory study. International Conference Rural, Research Planning Group(IC-RRPG), (August).

Karioja, E. (2013). Sustainability in libraries: A comparative study of ecological sustainability in IFLA WLIC 2012, 41+42.

Mansour, E. (2020). Libraries as agents for development: The potential role of Egyptian rural public libraries towards the attainment of Sustainable Development Goals based on the UN 2030 Agenda. Journal of Librarianship and Information Science, 52(1), 121-136. https://doi.org/10.1177/0961000619872064

Markulev, A., \& Long, A. (2013). On sustainability : An economic approach. Productivity Commission Staff Research Note, (May), 25-50.

Michnik, K. (2015). Public libraries digital services and sustainability issues. Bottom Line, 28(1-2), 34-43. https://doi.org/10.1108/BL-12-2014-0034

Morelli, J. (2011). Environmental sustainability: A definition for environmental professionals. Journal of Environmental Sustainability, 1(1), 1-10. https://doi.org/10.14448/jes.01.0002

Omar, S. Z., Shaffril, H. A. M., D’Silva, J. L., Bolong, J., Hamzah, A., \& D’Silva, J. L. (2014). Mapping the patterns and problems in using rural library services among rural youth in Malaysia. Information Development, 2014(June), 0266666913515506. https://doi.org/10.1177/0266666913515506

Rohman, A. S., \& Sukaesih, S. (2018). Transformasi perpustakaan desa untuk pemberdayaan masyarakat: Studi kasus di desa Margamukti - Pangalengan Bandung. Jurnal Perpustakaan Pertanian, 26(2), 47. https://doi.org/10.21082/jpp.v26n2.2017.p47-54

Spangenberg, J. H. (2005). Economic sustainability of the economy: Concepts and indicators. International Journal of Sustainable Development, 8(1/2), 47-65. https://doi.org/10.1504/IJSD.2005.007374

Spodick, E. (2016). Sustainability - it's everyone's job. Library Management, 37(6-7), 286297. https://doi.org/10.1108/LM-04-2016-0024

Townsend, A. K. (2014). Environmental sustainability and libraries: Facilitating user awareness. Library Hi Tech News, 31(9), 21-23. https://doi.org/10.1108/LHTN-07-20140059.

Arya, P., Srivastava, M. K., \& Jaiswal, M. P. (2019). Modelling environmental and economic sustainability of logistics. Asia-Pacific Journal of Business Administration, 12(1), 73-94. 
https://doi.org/10.1108/APJBA-11-2018-0204

Bakeri, A., Bakar, A., \& Putri, N. L. J. (2013). Sustainability through website development : The case of public libraries in Malaysia.

Connaway, L. S., \& Powell, R. R. (2015). Basic Research Methods for Librarians. PhD Proposal (Vol. 1). Libraries Unlimited. https://doi.org/10.1017/CBO9781107415324.004

Dent, V. F. (2007). Local economic development in Uganda and the connection to rural community libraries and literacy. New Library World, 108(5/6), 203-217. https://doi.org/10.1108/03074800710748777

Emas, R. (2015). The Concept of Sustainable Development: Definition and Defining Principles, Florida International University. Brief for GSDR 2015, 1-3. Retrieved from https://s3.amazonaws.com/academia.edu.documents/43652555/5839GSDR_2015_SD _concept_definiton_rev.pdf?response-content-disposition=inline $\% 3 \mathrm{~B}$ filename\%3DThe_Concept_of_Sustainable_Development_D.pdf\&X-AmzAlgorithm=AWS4-HMAC-SHA256\&X-Amz-Credential=AKIAIWOW

Fairbairn, J. (2012). Public libraries - an underused resource for development. Retrieved from http://www.scidev.net/index.cfm?originalUrl=global/communication/opinion/publiclibraries-an-underused-resource-fordevelopment.html\%5Cnhttp://www.scidev.net/global/communication/opinion/publiclibraries-an-underused-resource-for-development.html

Giovannoni, E., \& Fabietti, G. (2014). Integrated Reporting: Concepts and Cases that Redefine Corporate Accountability. In C. Busco, M. L. Frigo, A. Riccaboni, \& P. Quattrone (Eds.), Integrated Reporting: Concepts and Cases that Redefine Corporate Accountability (pp. 21-42). Switzerland. https://doi.org/10.1007/978-3-319-02168-3

Hancks, J. W. (2011). Keepin' it rural: The role of rural public library educational programming and outreach in community economic sustainability efforts.

Harris, J. M. (2003). Sustainability and sustainable development. Environmental Impact Assessment Review, 18(6), 493-520. https://doi.org/10.1016/S0195-9255(98)00019-5

Hoq, K. M. G. (2015). Rural library and information services, their success, failure and sustainability: a literature review. Information Development, 31(3), 294-310. https://doi.org/10.1177/0266666913515693

Jeekel, H. (2017). Social sustainability and smart mobility : Exploring the relationship. Transportation Research Procedia, 25, 4300-4314. https://doi.org/10.1016/j.trpro.2017.05.254

Jenkins, J. L., Quiroga, G., Quiballo, K., Peterson, H. A., \& Sorrell, R. (2018). Rural and Small Public Libraries: Challenges and Opportunities. Advances in Librarianship, 43, 37-59. https://doi.org/10.1108/S0065-283020170000043003

Kamarudin, K. H., \& Untari, R. (2018). Development of creative village and rural entrepreneurship in Malaysia and Indonesia : An exploratory study. International Conference Rural, Research Planning Group(IC-RRPG), (August).

Karioja, E. (2013). Sustainability in libraries: A comparative study of ecological sustainability in IFLA WLIC 2012, 41+42.

Mansour, E. (2020). Libraries as agents for development: The potential role of Egyptian rural public libraries towards the attainment of Sustainable Development Goals based on the UN 2030 Agenda. Journal of Librarianship and Information Science, 52(1), 121-136. https://doi.org/10.1177/0961000619872064

Markulev, A., \& Long, A. (2013). On sustainability : An economic approach. Productivity 
Commission Staff Research Note, (May), 25-50.

Michnik, K. (2015). Public libraries digital services and sustainability issues. Bottom Line, 28(1-2), 34-43. https://doi.org/10.1108/BL-12-2014-0034

Morelli, J. (2011). Environmental sustainability: A definition for environmental professionals. Journal of Environmental Sustainability, 1(1), 1-10. https://doi.org/10.14448/jes.01.0002

Omar, S. Z., Shaffril, H. A. M., D’Silva, J. L., Bolong, J., Hamzah, A., \& D’Silva, J. L. (2014). Mapping the patterns and problems in using rural library services among rural youth in Malaysia. Information Development, 2014(June), 0266666913515506. https://doi.org/10.1177/0266666913515506

Maskurotunitsa, R. S. Y. R. (2016). Peran perpustakaan desa “Mutiara" dalam pemberdayaan masyarakat Desa Kalisidi Kecamatan Ungaran Barat Kabaputen Semarang. Jurnal Ilmu Perpustakaan, 5, 81-90.

Rohman, A. S., \& Sukaesih, S. (2018). Transformasi perpustakaan desa untuk pemberdayaan masyarakat: Studi kasus di desa Margamukti - Pangalengan Bandung. Jurnal Perpustakaan Pertanian, 26(2), 47. https://doi.org/10.21082/jpp.v26n2.2017.p47-54

Spangenberg, J. H. (2005). Economic sustainability of the economy: Concepts and indicators. International Journal of Sustainable Development, 8(1/2), 47-65. https://doi.org/10.1504/IJSD.2005.007374

Spodick, E. (2016). Sustainability - it's everyone's job. Library Management, 37(6-7), 286297. https://doi.org/10.1108/LM-04-2016-0024

Townsend, A. K. (2014). Environmental sustainability and libraries: Facilitating user awareness. Library Hi Tech News, 31(9), 21-23. https://doi.org/10.1108/LHTN-07-20140059 


\section{Appendix (Interview Questions)}

Library Staff

1. Demographic questions (name, age, and work experience)

2. What is your educational background?

3. Do you understand the library policy, management, and job description of your position?

4. What is your initiative towards rural library development?

5. Do you think that the rural library has failed to serve its community?

6. How is rural library usage?

Rural Library User

1. Demographic questions (name, age, how long has the respondent lives in the village, the community the respondent belongs to, type of occupation, marriage status, and family income)

2. Frequency of going to the rural library.

3. Why do you go to the rural library?

4. Do you think that the library fulfills the environmental, economic, and social sustainability elements?

5. Do you think that the location of the rural library is strategic?

6. How about its interior design?

Rural Library Non-User

1. Demographic questions (name, age, how long has the respondent lives at the village, the community the respondent belongs to, type of occupation, marriage status, and family income)

2. Have you been to the library?

3. Why are you not using the library?

4. Do you think that the library should have environmental, economic, and social sustainability elements?

5. Do you think that the location of the rural library is strategic? 